of opinion about this and other matters led to a reorganization in 1931, by which the Council was transformed into the International Council of Scientific Unions. Under the new arrangement the Unions became autonomous within the framework of the new Council, the General Assembly was permitted to meet elsewhere than in Brussels, and adherence of a country to any Union no longer required adherence to the Council.

In 1946 the United Nations Educational, Scientific and Cultural Organization (Unesco) was formed and a formal and mutual draft agreement between Unesco and the International Council of Scientific Unions was approved by the Council in 1946 at its first General Assembly after the Second World War. This agreement was modified in 1947 and again in 1952. The present agreement is described in the year book of the Council, which also contains details of members of the various councils, statutes and rules, the activities of the Council and the state of its finances.

\section{WEIGHING IN THE LABORATORY}

THE principles of the design, adjustment, use and testing of good-quality lsnife-edge balances and weights employed for precise weighing in scientific laboratories forms the subject of the seventh in the series of "Notes on Applied Science" issued by the Department of Scientific Research*. The information given, which is based largely on the experience gained at the National Physical Laboratory, Teddington, in maintaining the standards of mass and in testing weights and balances, should be of great value to those in industry and research who are concerned with precise weighings.

The contents, which are in two parts dealing respectively with knife-edge balances and weights, are much more detailed than in previous numbers of the series and include illustrations of the precision 1-kgm. balance at the National Physical Laboratory which is used for the cornparison of national standards of mass, of the Imperial Standard Pound and the British National Copy of the International Kilogramme, and several tables and three appendixes. In Part 1 the chief features -functioning and adjustment of the simple equal-arm balance-are outlined clearly and fully with particular emphasis on the essential practical requirements. Various types of balance are discussed, and comparative information is summarized in two useful tables. The methods and technique of weighing are described, and net buoyancy corrections to obtain mass from weighings in air, and values of the density of air for the ranges $5-30^{\circ} \mathrm{C}$. and $600-800 \mathrm{~mm}$. of mercury are tabulated. A clear distinction is drawn between the conceptions of sensitivity and accuracy of performance of a balance, and a guide is given to the varieties of balances readily available.

In Part 2 the suitability of the various materials used for the construction of weights is considered first. Plain polished brass is unsatisfactory; and, of the coating materials, lacquer is too hygroscopic, uncoated nickel plating fogs and gold plating is often porous and is also liable to loss of weight due to wear. The construction, adjustment and tolerances * National Physical Laboratory Notes on Applied Science. No. 7 :
Balances, Weights and Precise Laboratory Weighing. Pp. iv $+42+$ plates. (London: H.M.S.O. 1954.) 2s. net. are discussed next, followed by a brief description of the tests and methods of verification of weights carried out at the National Physical Laboratory, which will be of considerable interest to those who are contemplating sending weights for test at the Laboratory or who intend to carry out their own tests.

In the three appendixes, the simple fundamental analysis of the equal-arm undamped knife-edge balance substantially as given in Glazebrook's "Dictionary of Applied Physics", the mathematical discussion of the motion of the damped beam, and the effect of air-buoyancy on a single-pan balance are given separate treatment.

\section{AGES OF URANINITES BY A NEW METHOD}

\section{BY DR. B. WASSERSTEIN \\ Geological Survey, Pretoria}

TN a previous communication in Nature N $^{1}$ I suggested that the generation by radioactive decay of smaller atoms of tetravalent lead within the crystal lattice of uraninites caused a shrinkage in the unit cell proportionate to time; some preliminary results were given in a table. Using artificial uranium oxide $\left(\mathrm{UO}_{2}\right)$ as an end-point to denote zero time, four results clearly supported the thesis; but three others, agreeing well among themselves, wore apparently too high and in conflict. Further work has indicated an obvious solution, namely, that there are, in fact, two different types of uraninites involved: those agreeing with the thesis I call $\alpha$-uraninites and are considered normal ; those which are apparently anomalous are called $\gamma$-uraninites.

The pitchblendes are classified as $\beta$-uraninites. As their spectra are usually too poor for accurate measurement, they are for the moment disregarded for age determinetion. Present work indicates that they are abnormally high in oxygen; this excess can be removed by heating in hydrogen to give cube-edges comparable with $\alpha$-uraninites for purposes of age determinations; these results will bo shortly announced.

The characteristic foature of $\gamma$-uraninites is that their cube-edges are reduced on heating in air to correspond to that of an $\alpha$-type analogue, whereas $\alpha$-uraninites upon similar treatmont disintegrate to give an X-ray pattern of $\mathrm{U}_{3} \mathrm{O}_{8}$. This phenomenon was first detected in two analysed samples, previously given as from Namaqualand, but more accurately, from the Gordonia district, South Africa ${ }^{1}$. In presenting the dat\&, a thoria correction-also discussed previously -has to be applied, and this is $-0.0013 \mathrm{~A}$. for each per cent $\mathrm{ThO}_{2}$ when $\mathrm{ThO}_{2}+\mathrm{UO}_{2}$ total 100 per cent--this suffices for a first approximation. The thoria content differs slightly in the two samples, which gave the following results :

\begin{tabular}{lcc} 
& \multicolumn{2}{c}{ GordonIA } \\
& (Holmes) & (Mountain) \\
& $\gamma$-type & $\alpha$-type \\
Untreated & $5 \cdot 485 \mathrm{~A}$. & $5 \cdot 444 \mathrm{~A}$. \\
Corrected for $\mathrm{ThO}_{2}$ & $5 \cdot 462 \mathrm{~A}$. & $5 \cdot 428 \mathrm{~A}$. \\
Heated & $5 \cdot 450 \mathrm{~A}$. & (disintegrates) \\
Corrected for $\mathrm{ThO}_{2}$ & $5.427 \mathrm{~A}$. &
\end{tabular}

